Article

\title{
Comparative Study on Leaf Gas Exchange, Growth, Grain Yield, and Water Use Efficiency under Irrigation Regimes for Two Maize Hybrids
}

\author{
Muhammad Irfan Ahmad ${ }^{1,+}$, Adnan Noor Shah ${ }^{1,+}{ }^{\mathbb{D}}$, Jianqiang Sun ${ }^{2}$ and Youhong Song ${ }^{1, *}$ \\ 1 School of Agronomy, Anhui Agricultural University, Hefei 230036, China; \\ irfan306@outlook.com (M.I.A.); ans.786@yahoo.com (A.N.S.) \\ 2 The Farming Development Center of Mengcheng County, Mengcheng 233500, China; 13030653415@163.com \\ * Correspondence: y.song@ahau.edu.cn; Tel.: +86-152-5513-5598 \\ + These authors have contributed equally to this work.
}

Received: 9 July 2020; Accepted: 11 August 2020; Published: 20 August 2020

check for updates

\begin{abstract}
Drought stress has been a great challenge for the sustainability of maize (Zea mays L.) production in arid and semi-arid regions. The utilization of drought-tolerant hybrids and proper irrigation regimes represent a management strategy to stabilize maize production under water-limited conditions. A two-year field experiment was conducted to assess the leaf gas exchange, growth, grain yield, and water use efficiency in two cultivars of maize, i.e., Zhengdan 958 (H1) and Zhongdan 909 (H2), under different water regimes, i.e., full irrigation (FI), reproductive irrigation (RI), and rainfed (RF). Plant samples were collected at different growth stages to measure the maize growth and development under the three irrigation regimes. The grain yield in RF was significantly reduced by $30.4 \%(\mathrm{H} 1)$ and $31.1 \%(\mathrm{H} 2)$; and the water use efficiency (WUE) by $8.5 \%(\mathrm{H} 1)$ and $9.3 \%(\mathrm{H} 2)$ compared with FI. On the other hand, irrigation application at the flowering stage was shown to significantly boost the grain yield by $40.3 \%(\mathrm{H} 1)$ and $25.5 \%(\mathrm{H} 2)$; and the WUE by $27.6 \%(\mathrm{H} 1)$ and $14.1 \%$ (H2) compared to RF. This indicated that $\mathrm{H} 1$ benefited more from irrigation use compared to $\mathrm{H} 2$. The improved grain yield through reproductive irrigation was due to the greater soil plant analysis development (SPAD), net photosynthesis, and biomass production when compared to zero irrigation. Zhengdan 958 was shown to be relatively more resistant to drought stress during flowering compared to Zhongdan 909. Thus, to achieve reliable maize production in Huaibei Plain, reproductive irrigation is recommended, combined with Zhengdan 958.
\end{abstract}

Keywords: drought stress; Zea mays L.; irrigation; rainfed; photosynthesis; Zhengdan 958; Zhongdan 909

\section{Introduction}

Increased vulnerability due to climate change may occur in many regions. Climate change will lead to more frequent or severe drought stress, resulting in more risk for crops [1]. Drought is one of the most fundamental environmental stresses that limits crop yield in many places in the world, especially in arid and semi-arid areas [2]. Huaibei Plain is an important area for food supply in China, located at south Huai-Huai-Hai, where the winter wheat (Triticum aestivum L.) and summer maize crops (Zea mays L.) are cultivated with a rotation [3]. Maize is known as one of the world's leading and most vital food security and feed crops [4]. Maize utilization has continued to grow gradually with exceeding demand in China because it serves as a valuable source of industrial material and urban nutrition products [5]. The demand for maize is expected to be doubled between now and 2050 [6]. Researchers [7,8] documented that, under vulnerable environmental change, the expending magnitudes, time periods, and the rate of droughts will intensely decrease the soil water availability for plant up-take, and maize production is susceptible to this phenomenon. 
Maize plants grown in Northern China are generally affected by water deficiency, and drought stress in the early and later stages of the plant considerably diminish the grain yield [9]. All the crops suffer from drought in the summer season where the rainfall is low; however, maize plants suffer more due to a shortage of water reducing the growth and development under water deficit conditions [10]. Maize yield reduction due to water stress depends on a lot of factors including plant developmental stages, severity and duration of water limitations, hybrid susceptibility and vulnerability to soil drought [11]. Maize is sensitive to soil moisture deficiency during vegetative and reproductive growth stages. During vegetative growth period plants reduce the leaf area index, plant height, diameter of stem, number of leaves, dry matter accumulation, chlorophyll contents, net photosynthesis and transpiration rate. Nonetheless, reproductive stages under drought stress are more critical to cause greater reduction in grain yield as compared to vegetative stages [12].

The flowering stage was found to be the most sensitive stage to water shortage, leading to reductions in crop growth, biomass production, and grain yield [12-15]. Thus, the water stress two weeks before flowering had a negative effect on silk growth, the opening of anthers, and anthesis [16]. Research demonstrated that the reduction in yield shifted by $10-76 \%$ depending on the drought frequency and the sensitivity of the crop and its growth period. The highest potential yield reduction happens during the silking period. Other study provided the evidence if the deficit of water occurs before or during silking and pollination resulted to reduction in kernel number and kernel weight [17]. Water stress at pre-anthesis stage cause more reduction in number of kernels [18]. Stress during the flowering period can substantially reduce the final grain yield by $35-50 \%$ [19]. Thus, supplying supplementary irrigation at the reproductive period during maize development is fundamental to achieve high yield.

The main objectives of this study were: (i) to investigate drought impacts during flowering on maize grain yield and the yield gap between rainfed and full irrigation; (ii) to compare the effects of flowering irrigation between hybrids; and (iii) to examine the interaction between three irrigation applications and two maize hybrids on growth and grain yield.

\section{Material and Methods}

\subsection{Experimental Site, Conditions, and Cultivars}

A two-year field research study was conducted on 6 June 2017 and 9 June 2018 in the experimental farm of Mengcheng Agricultural Scientific Institute located in Huaibei plain, Anhui Province, China $\left(33^{\circ} 9^{\prime} 44^{\prime \prime} \mathrm{N}, 116^{\circ} 32^{\prime} 5^{\prime \prime} \mathrm{E}\right)$. The typical soil type of this area has low organic matter and poor soil fertility known as lime concretion black soil which enhances cultivation barrier [20]. The cropping in semiarid Huaibei Plain mainly depends on natural rainfall and only limited irrigation may apply when severe drought occurs.

The soil of the experimental farm was a typical lime concentration black soil containing available $\mathrm{N}$ content at $0.97 \mathrm{~g} \mathrm{~kg}^{-1}, 52.5 \mathrm{mg} \mathrm{kg}^{-1} \mathrm{P}_{2} \mathrm{O}_{5}, 112.5 \mathrm{mg} \mathrm{kg}^{-1} \mathrm{~K}_{2} \mathrm{O}, 25.5 \mathrm{~g} \mathrm{~kg}^{-1}$ organic matter, and a $4.85 \mathrm{pH}$. The maize cultivars, i.e., Zhengdan 958 and Zhongdan 909, were sown. Zhengdan 958 is a high yielding, middle maturity, and compact-type drought resistance variety [21]. Zhongdan 909 is a modern high yielding hybrid with middle maturity, that requires more water to provide a high yield [22]. Weather data of the daily temperature, total rainfall, and solar radiation for two years were collected from the meteorological department of Mengcheng Agricultural Scientific Institute (Figure 1). 


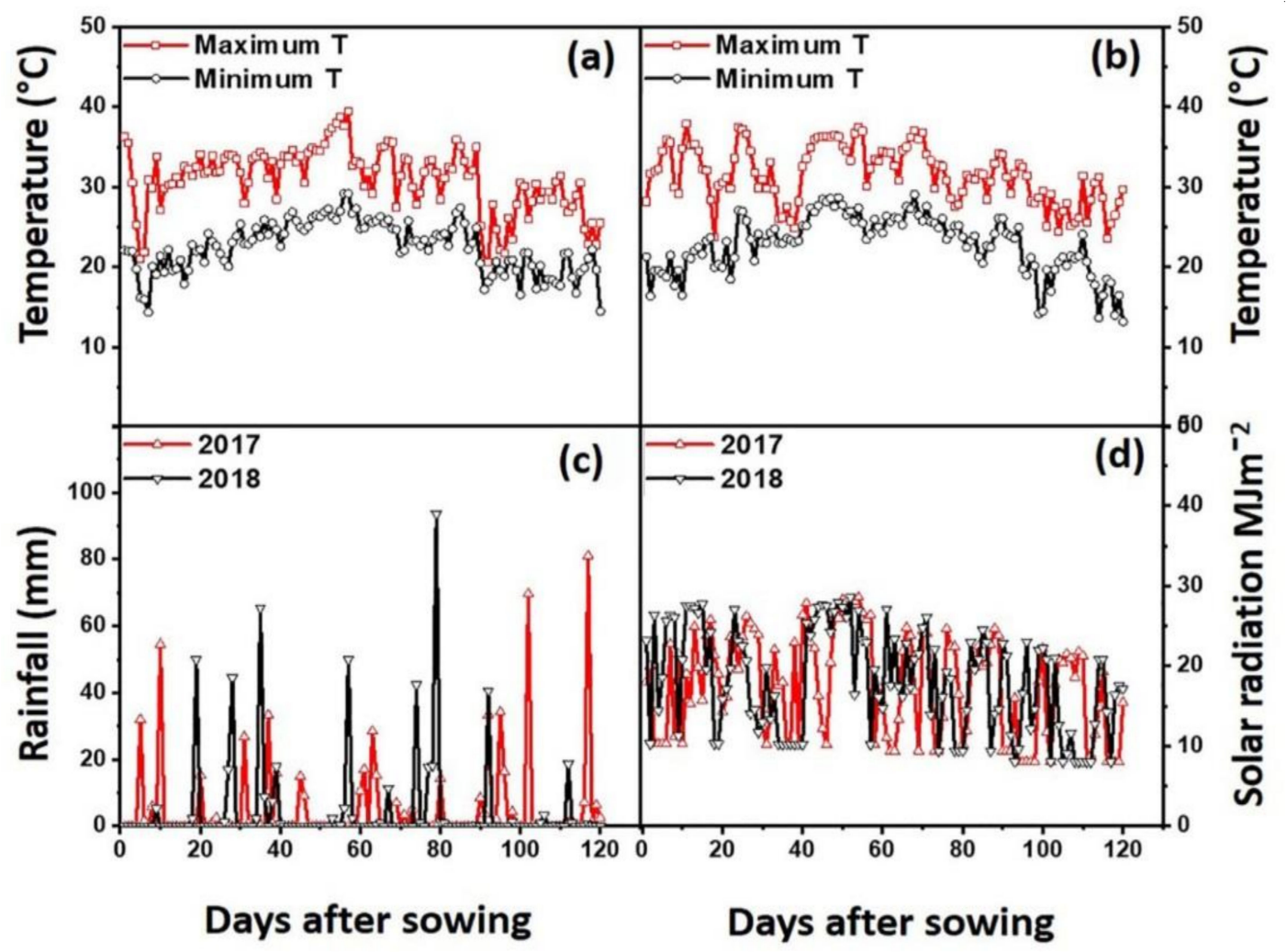

Figure 1. Weather conditions in 2017 and 2018 during the crop growing season. (a) Temperature $\left({ }^{\circ} \mathrm{C}\right)$ in 2017, (b) temperature $\left({ }^{\circ} \mathrm{C}\right.$ ) in 2018 , (c) total rainfall (mm) of 577.1 and 540.2 in 2017-2018 respectively and (d) solar radiation $\left(\mathrm{MJ} \mathrm{m}^{-2}\right)$ in 2017-2018.

\subsection{Experimental Design, Treatments and Crop Management}

A field study was designed with three irrigations using the flooded method composed of $180 \mathrm{~mm}$ irrigation (fully irrigated, FI), was applied at $60 \mathrm{~mm}$ at the big flare, flowering, and mid grain stages, respectively, $60 \mathrm{~mm}$ irrigation (reproductive irrigation, RI), and $0 \mathrm{~mm}$ irrigation (rainfed, RF), were applied at the flowering stage in a randomized complete block design (RCBD) with split arrangement along with three replicates. Two factors, i.e., irrigations and hybrids, were used in the experiment, with the main plots being hybrids and the subplots being different irrigations. A row spacing of $60 \mathrm{~cm}$ was used with a plant to plant space of $25 \mathrm{~cm}$ to achieve the desired planting population of 6.74 plants $\mathrm{m}^{-2}$ $\left(66,667\right.$ plants ha $\left.{ }^{-1}\right)$.

Maize seeds were manually sown, and the seedlings were thinned at 20 days after the emergence (DAE) of plants to maintain the required planting population. The fertilizers were applied at $300(\mathrm{~N})$, $112(\mathrm{P})$, and $112(\mathrm{~K}) \mathrm{kg} \mathrm{ha}^{-1}$, respectively. The sources of fertilizers were urea $(46.4 \% \mathrm{~N})$, calcium superphosphate $\left(12 \% \mathrm{P}_{2} \mathrm{O}_{5}\right)$, and potassium chloride $\left(60 \% \mathrm{~K}_{2} \mathrm{O}\right)$. The $\mathrm{P}$ and $\mathrm{K}$ were applied at the time of sowing as basal fertilizer but $\mathrm{N}$ fertilizer was applied at the rate of $300 \mathrm{~kg} \mathrm{ha}^{-1}$ but split into two doses, $50 \%$ was applied at the time of sowing and the remaining $50 \%$ was applied on the 15 July 2017 and the 18 July 2018. All other agronomic management practices were the same during the experimental work.

\subsection{Data Collection}

\subsubsection{Soil Moisture Contents}

The soil moisture contents were determined at the jointing, big flare, flowering, initial grain filling, mid grain, and harvesting stages in growing seasons of both 2017 and 2018. The soil samples were taken at a depth of 10, 20,30, and $40 \mathrm{~cm}$, and the fresh weight of the soil was noted before placing 
the soil samples into the oven for drying. The moisture contents were recorded using the gravimetric method. The experiment in both years was conducted in three replicates.

\subsubsection{Phenology}

Ten plants were selected randomly from each treatment and tagged after emergence, and then we counted the number of days taken by plants to complete different stages [23].

\subsubsection{Leaf Chlorophyll Content (Soil Plant Analysis Development (SPAD))}

The SPAD-502 (Konica-Minolta Sensing, Osaka, Japan) chlorophyll meter was used to measure the leaf relative chlorophyll content $[23,24]$. Three plants and their two types of leaves were selected from each treatment to measure the SPAD values. During this measurement, the upper fully expanded leaf was selected at the jointing, big flare and flowering stages. The cob leaf was selected at the initial and mid grain stages. The whole leaf value was measured by calculating the average value of three points i.e., the tip, middle, and bottom.

\subsubsection{Photosynthetic Attributes}

Three random plants were selected from each plot to measure the photosynthesis and its attributes. A portable photosynthesis system CIRAS-3 (PP Systems, Amesbury, MA, USA) was used on a clear sunny day between 9 AM to $12 \mathrm{PM}$ to record the net photosynthesis (Pn), stomatal conductance (gs), $\mathrm{CO}_{2}$ intercellular concentration $(\mathrm{Ci})$, and transpiration rate (Tr). The surge flask was used to control the environmental conditions in the leaf chamber.

\subsubsection{Plant Dry Biomass}

Three plants were selected randomly at different growth stages from each treatment, and we took the fresh weight of each plant, and then divided the vegetative and reproductive parts of each plant separately. After that, we oven-dried the separated parts of the plants at $70{ }^{\circ} \mathrm{C}$ until they reached a constant weight, and then we measured the dry weight.

\subsubsection{Physiological Maturity}

Before harvesting, the presence of a black layer was observed at the base of the grain, which indicated that no further accumulation of grain mass was possible [25]. The grain from the base, mid and distal end of cob was removed to check the base of the black layer. The crop was considered ready to harvest when $75 \%$ of the grain had developed a black layer.

\subsubsection{Yield and Yield Components}

After the physiological maturity, twenty cobs were taken from each treated plot to determine the cob length $(\mathrm{cm})$, cob diameter $(\mathrm{cm})$, number of lines per cob, number of kernels per cob, 1000-kernel weight $(\mathrm{g})$, and grain yield $\left(\mathrm{kg} \mathrm{ha}^{-1}\right)$. A Vernier caliper was used to measure the cob length $(\mathrm{cm})$ and diameter (mm). The number of kernels per cob was counted manually. The weight of 1000-kernels were noted from the sample of each treatment and weighed in grams using an electronic balance. For the grain yield, the middle two rows of maize plants were cut by a small household corn thresher from each plot. The cobs were separated from harvested plants and dried in the sunshine for 10 days and then weighed.

\subsubsection{Water Use Efficiency (WUE) and Harvest Index (\%)}

The water use efficiency $\left(\mathrm{Kg} \mathrm{ha}^{-1} \mathrm{~mm}^{-1}\right)$ was computed using Equation (1) by [17].

$$
\begin{gathered}
\text { WUE }=\frac{Y}{E T a} \\
E T a=P+I+C r-R-D \pm \Delta S
\end{gathered}
$$


The WUE means that the quantity of water consumed by crops is estimated according to the total amount of water used from the plant and soil surfaces in addition to that retained within plant structures. $\mathrm{Y}$ is the maize grain yield $\left(\mathrm{kg} \mathrm{ha}^{-1}\right)$. Where ETa is the evapotranspiration $(\mathrm{mm}), \mathrm{P}$ is the seasonal cumulative rainfall $(\mathrm{mm})$; I is the total seasonal irrigation $(\mathrm{mm})$; $\mathrm{Cr}$ is the seasonal upward capillary flow into the root zone $(\mathrm{mm}), \mathrm{R}$ is the surface runoff $(\mathrm{mm}), \mathrm{D}$ is the downward flux below the crop root zone.

$\mathrm{Cr}, \mathrm{R}$, and $\mathrm{D}$ were considered to be zero because surface runoff was non-existent and negligible capillary rising from $20-30 \mathrm{~m}$ below the soil surface during growing season. $\Delta \mathrm{S}$ stands for the difference between the soil water storage at seeding and at harvest $(0-40 \mathrm{~cm})$.

The harvest index (HI) \% was computed using Equation (3) by [26].

$$
\mathrm{HI}(\%)=\frac{\text { Grain Yield }}{\text { Biological Yield }} \times 100
$$

$\mathrm{HI}$ is a measure of the efficiency of plants in producing seeds. It is the ratio of grain yield to total above ground biomass.

At harvest maturity, the middle two rows of maize plants were cut from each treatment, and the material was sun-dried up to a constant weight. Weighed and then converted into biological yield/biomass $\left(\mathrm{kg} \mathrm{ha}^{-1}\right)$. The harvested material for biomass yield was threshed. The grains were separated and weighed, and then converted into grain yield $\left(\mathrm{kg} \mathrm{ha}^{-1}\right)$.

\subsection{Data Analysis}

All statistical analysis was performed by using SPSS 18.0 (SPSS Inc., Chicago, IL, USA). The mean differences among treatments were calculated using LSD at $(p<0.05)$. The figures were organized using Origin 8.0 (Origin Lab) software.

\section{Results}

\subsection{Soil Moisture}

The soil moisture in different irrigation regimes is presented in Table 1 . The soil moisture under RF was significantly reduced by $22.3 \%$ for Zhengdan 958 (H1) and $23.7 \%$ for Zhongdan 909 (H2) in 2017; and $23.1 \%$ (H1) and $24.8 \%$ (H2) in 2018 compared to the FI at the grain filling stage. However, the moisture content in the RF was significantly lower by $9.6 \%(\mathrm{H} 1)$ and $11.2 \%(\mathrm{H} 2)$ in 2017 ; and $12.0 \%(\mathrm{H} 1)$ and $15.2 \%(\mathrm{H} 2)$ in 2018 compared to the RI at the grain filling stage.

\subsection{Maize Phenology}

The phenological data of both years are presented in Table 2. Both hybrids H1 and H2 under FI took a similar number of days to complete the initial grain filling and mid grain filling stages in 2017 and 2018. H1 under RI just one day prior took to complete flowering stage and two days later to complete mid grain filling stage compared to $\mathrm{H} 2$ under RI in both years. However, H2 under FI took the maximum days, 115 and 111 in 2017 and 2018, respectively, to complete its maturity followed by $\mathrm{H} 1$ under FI to complete its maturity one day earlier in both years. H2 under RF took the least number of days 109 in 2017 and 106 days in 2018 to complete its maturity (Table 2). 
Table 1. The soil profile at 0-40 cm moisture (\%) as affected by different water regimes in the growing season in 2017 and 2018 .

\begin{tabular}{cccccccc}
\hline Year & Treatments & Jointing Stage & Big Flare Stage & Flowering Stage & Initial Grain Stage & Mid Grain Stage & Harvesting Stage \\
\hline \multirow{2}{2017}{} & FIH1 & $9.68 \pm 0.02 \mathrm{a}$ & $12.54 \pm 0.25 \mathrm{a}$ & $13.77 \pm 0.10 \mathrm{a}$ & $11.11 \pm 0.07 \mathrm{a}$ & $23.76 \pm 0.13 \mathrm{a}$ & $15.83 \pm 0.12 \mathrm{a}$ \\
& RIH1 & $9.75 \pm 0.01 \mathrm{a}$ & $12.52 \pm 0.24 \mathrm{a}$ & $10.51 \pm 0.20 \mathrm{c}$ & $9.55 \pm 0.15 \mathrm{c}$ & $22.21 \pm 0.12 \mathrm{c}$ & $14.52 \pm 0.19 \mathrm{c}$ \\
& RFH1 & $9.73 \pm 0.02 \mathrm{a}$ & $12.35 \pm 0.18 \mathrm{a}$ & $10.35 \pm 0.04 \mathrm{~cd}$ & $8.63 \pm 0.06 \mathrm{e}$ & $20.66 \pm 0.22 \mathrm{e}$ & $13.04 \pm 0.10 \mathrm{e}$ \\
& FIH2 & $9.23 \pm 0.03 \mathrm{~b}$ & $11.58 \pm 0.07 \mathrm{~b}$ & $13.18 \pm 0.02 \mathrm{~b}$ & $10.52 \pm 0.18 \mathrm{~b}$ & $22.91 \pm 0.18 \mathrm{~b}$ & $15.25 \pm 0.21 \mathrm{~b}$ \\
& RIH2 & $9.32 \pm 0.12 \mathrm{~b}$ & $11.67 \pm 0.08 \mathrm{~b}$ & $10.18 \pm 0.15 \mathrm{~d}$ & $9.05 \pm 0.05 \mathrm{~d}$ & $21.43 \pm 0.20 \mathrm{~d}$ & $13.94 \pm 0.07 \mathrm{~d}$ \\
& RFH2 & $9.27 \pm 0.03 \mathrm{~b}$ & $11.64 \pm 0.23 \mathrm{~b}$ & $10.33 \pm 0.03 \mathrm{~cd}$ & $8.03 \pm 0.12 \mathrm{f}$ & $19.90 \pm 0.22 \mathrm{f}$ & $12.62 \pm 0.07 \mathrm{e}$ \\
\hline \multirow{2}{2018}{} & FIH1 & $10.50 \pm 0.08 \mathrm{a}$ & $11.66 \pm 0.06 \mathrm{a}$ & $12.52 \pm 0.10 \mathrm{a}$ & $10.92 \pm 0.07 \mathrm{a}$ & $25.49 \pm 0.08 \mathrm{a}$ & $15.59 \pm 0.07 \mathrm{a}$ \\
& RIH1 & $10.44 \pm 0.06 \mathrm{a}$ & $11.49 \pm 0.13 \mathrm{a}$ & $9.62 \pm 0.13 \mathrm{~cd}$ & $9.63 \pm 0.08 \mathrm{c}$ & $23.90 \pm 0.07 \mathrm{c}$ & $14.22 \pm 0.06 \mathrm{~b}$ \\
& RFH1 & $10.49 \pm 0.09 \mathrm{a}$ & $11.48 \pm 0.08 \mathrm{a}$ & $9.67 \pm 0.06 \mathrm{c}$ & $8.40 \pm 0.08 \mathrm{e}$ & $21.66 \pm 0.28 \mathrm{~d}$ & $12.85 \pm 0.04 \mathrm{c}$ \\
& FIH2 & $10.40 \pm 0.11 \mathrm{a}$ & $11.74 \pm 0.10 \mathrm{a}$ & $12.01 \pm 0.06 \mathrm{~b}$ & $10.52 \pm 0.18 \mathrm{~b}$ & $25.01 \pm 0.13 \mathrm{~b}$ & $15.33 \pm 0.12 \mathrm{a}$ \\
& RIH2 & $10.36 \pm 0.02 \mathrm{a}$ & $11.81 \pm 0.04 \mathrm{a}$ & $9.29 \pm 0.03 \mathrm{~d}$ & $9.34 \pm 0.05 \mathrm{~d}$ & $23.77 \pm 0.07 \mathrm{c}$ & $14.16 \pm 0.09 \mathrm{~b}$ \\
& RFH2 & $10.35 \pm 0.05 \mathrm{a}$ & $11.64 \pm 0.23 \mathrm{a}$ & $9.44 \pm 0.17 \mathrm{~cd}$ & $7.91 \pm 0.03 \mathrm{f}$ & $21.33 \pm 0.13 \mathrm{~d}$ & $12.57 \pm 0.04 \mathrm{c}$ \\
\hline
\end{tabular}

In the treatment column: FI is showing full irrigation (180 mm), RI is showing reproductive irrigation (60 mm), RF is showing rainfed, H1 is showing hybrid (Zhengdan 958$)$, and $\mathrm{H} 2$ is showing hybrid (Zhongdan 909). In data table \pm indicates standard deviation, and different letters indicate significant differences among treatments $(p<0.05)$.

Table 2. Maize phenology and growth periods taken from irrigation frequencies.

\begin{tabular}{|c|c|c|c|c|c|c|c|}
\hline \multicolumn{8}{|c|}{ Growing Period (days) } \\
\hline Year & Treatments & Jointing Stage & Big Flare Stage & Anthesis Stage & Initial Grain Stage & Mid Grain Stage & Physiological Maturity \\
\hline \multirow{6}{*}{2017} & FIH1 & $28.27 \mathrm{a}$ & $42.80 \mathrm{a}$ & $62.55 \mathrm{~b}$ & $76.01 \mathrm{a}$ & $89.62 \mathrm{a}$ & $114.14 \mathrm{ab}$ \\
\hline & RIH1 & $28.15 \mathrm{a}$ & $43.04 \mathrm{a}$ & $62.83 \mathrm{ab}$ & 75.99 a & $88.20 \mathrm{a}$ & $113.64 \mathrm{ab}$ \\
\hline & RFH1 & $28.11 \mathrm{a}$ & $43.03 \mathrm{a}$ & $64.05 \mathrm{ab}$ & $75.04 \mathrm{ab}$ & $85.34 a$ & $110.77 \mathrm{~cd}$ \\
\hline & FIH2 & $28.43 \mathrm{a}$ & $42.83 \mathrm{a}$ & $62.65 \mathrm{ab}$ & $76.03 \mathrm{a}$ & $89.60 \mathrm{~b}$ & $115.36 \mathrm{a}$ \\
\hline & RIH2 & $28.14 \mathrm{a}$ & $43.03 \mathrm{a}$ & $63.32 \mathrm{ab}$ & $75.52 \mathrm{ab}$ & $86.07 \mathrm{~b}$ & $112.57 \mathrm{bc}$ \\
\hline & RFH2 & 28.17 a & $43.06 \mathrm{a}$ & $64.49 \mathrm{~b}$ & $73.70 \mathrm{~b}$ & $84.66 \mathrm{~b}$ & $109.00 \mathrm{~d}$ \\
\hline \multirow[t]{6}{*}{2018} & FIH1 & $27.09 \mathrm{a}$ & $41.10 \mathrm{a}$ & $60.14 \mathrm{c}$ & $73.18 \mathrm{ab}$ & $86.22 \mathrm{a}$ & $110.18 \mathrm{ab}$ \\
\hline & RIH1 & $27.03 \mathrm{a}$ & $41.32 \mathrm{a}$ & $60.39 c$ & $73.05 \mathrm{ab}$ & $85.18 \mathrm{~b}$ & $109.13 \mathrm{~b}$ \\
\hline & RFH1 & $27.08 \mathrm{a}$ & $41.34 \mathrm{a}$ & $62.27 \mathrm{ab}$ & $72.02 \mathrm{c}$ & $82.96 \mathrm{c}$ & $107.29 \mathrm{c}$ \\
\hline & $\mathrm{FIH} 2$ & $27.15 \mathrm{a}$ & $41.15 \mathrm{a}$ & $60.19 c$ & $73.4 \mathrm{a}$ & $86.38 \mathrm{a}$ & $111.00 \mathrm{a}$ \\
\hline & RIH2 & $27.13 \mathrm{a}$ & $41.36 \mathrm{a}$ & $61.09 \mathrm{bc}$ & $72.97 \mathrm{~b}$ & $83.40 \mathrm{c}$ & $108.95 \mathrm{~b}$ \\
\hline & RFH2 & $27.11 \mathrm{a}$ & $41.38 \mathrm{a}$ & $63.12 \mathrm{a}$ & $70.2 \mathrm{~d}$ & $82.14 \mathrm{~d}$ & $106.28 \mathrm{~b}$ \\
\hline
\end{tabular}

In the treatment column: FI is showing full irrigation (180 mm), RI is showing reproductive irrigation (60 mm), RF is showing rainfed, H1 is showing hybrid (Zhengdan 958$)$, and $\mathrm{H} 2$ is showing hybrid (Zhongdan 909). In data table \pm indicates standard deviation, and different letters indicate significant differences among treatments $(p<0.05)$. 


\subsection{Leaf Chlorophyll Contents}

At the big flare stage, the SPAD values in RF were significantly reduced by $6.5 \%(\mathrm{H} 1)$ and $7.4 \%(\mathrm{H} 2)$ in 2017; and 7.3\% (H1) and 8.6\% (H2) in 2018, compared to FI. SPAD in H2 was clearly reduced more compared to $\mathrm{H} 1$. At the flowering stage, the SPAD values in RF were reduced by $8.9 \%(\mathrm{H} 1)$ and $8.8 \%(\mathrm{H} 2)$ in 2017 and $7.8 \%(\mathrm{H} 1)$ and $9.1 \%(\mathrm{H} 2)$ in 2018 compared with FI. However, the SPAD values in RI were significantly improved by $8.1 \%(\mathrm{H} 1)$ and $7.4 \%(\mathrm{H} 2)$ in 2017 and $5.3 \%(\mathrm{H} 1)$ and $7.9 \%(\mathrm{H} 2)$ in 2018 compared to RF due to irrigation at the flowering stage (Figure 2).
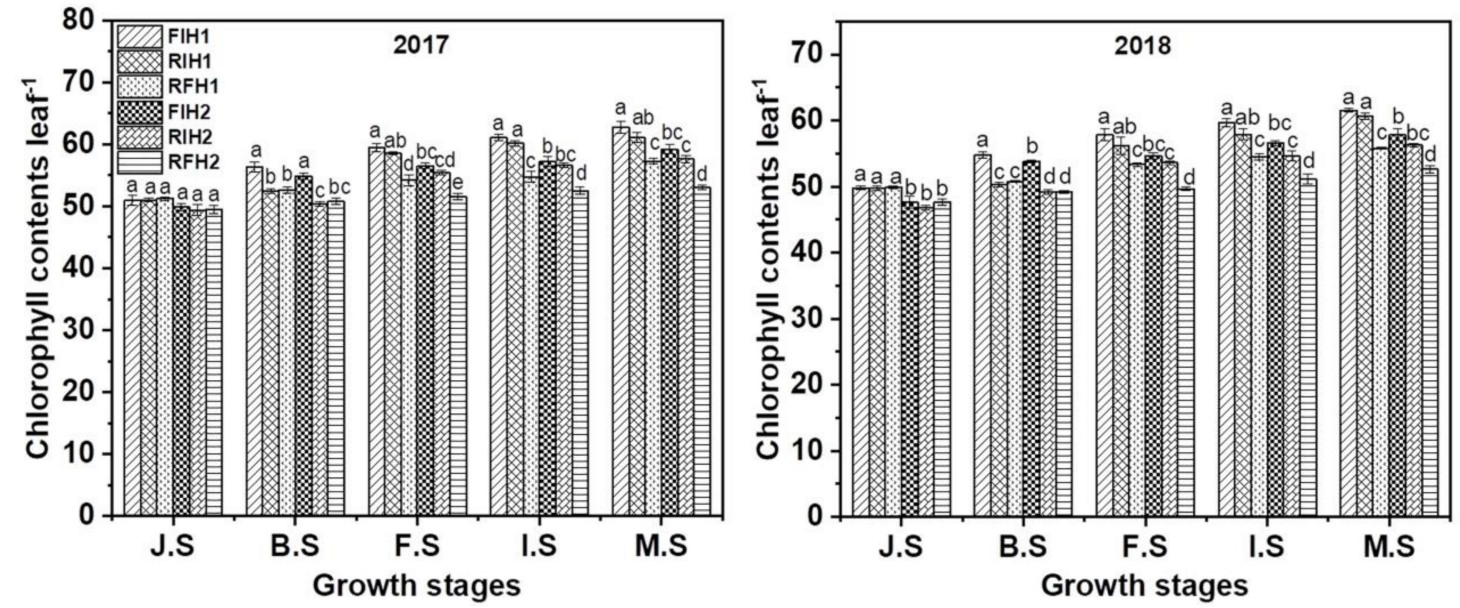

Figure 2. The leaf chlorophyll contents at different growth stages in the years 2017-2018. In treatments: J.S is the jointing stage, B.S is the big flare stage, F.S is the flowering stage, I.S is the initial grain stage, and M.S is the mid grain stage. FI is the full irrigation $(180 \mathrm{~mm}), \mathrm{RI}$ is reproductive irrigation $(60 \mathrm{~mm})$, $\mathrm{RF}$ is rainfed, H1 is hybrid Zhengdan 958, and H2 is hybrid Zhongdan 909. Different letters indicate significant differences among treatments $(p<0.05)$.

\subsection{Leaf Photosynthetic Attributes}

Different irrigation regimes and hybrids were significantly affected by the net photosynthesis (Pn) values of the upper fully expanded leaf in maize as shown (Figure 3). At the jointing stage, the Pn values were not significantly affected by irrigation. In contrast, the Pn values were found to be significantly different between hybrids. At the big flare stage, the Pn values in RF were considerably reduced by $21.8 \%(\mathrm{H} 1)$ and $32.9 \%(\mathrm{H} 2)$ in 2017 ; and $29.3 \%(\mathrm{H} 1)$ and $27.3 \%(\mathrm{H} 2)$ in 2018 , compared to FI. At the flowering stage, the Pn values in RF were significantly decreased by $25.0 \%(\mathrm{H} 1)$ and $26.2 \%(\mathrm{H} 2)$ in 2017; and $25.4 \%$ (H1) and $24.4 \%$ (H2) in 2018, compared to FI. However, the Pn values in RI were also significantly increased by $30.7 \%(\mathrm{H} 1)$ and $21.0 \%(\mathrm{H} 2)$ in 2017 and $31.4 \%(\mathrm{H} 1)$ and $20.8 \%(\mathrm{H} 2)$ in 2018, compared to RF (Figure 3). 


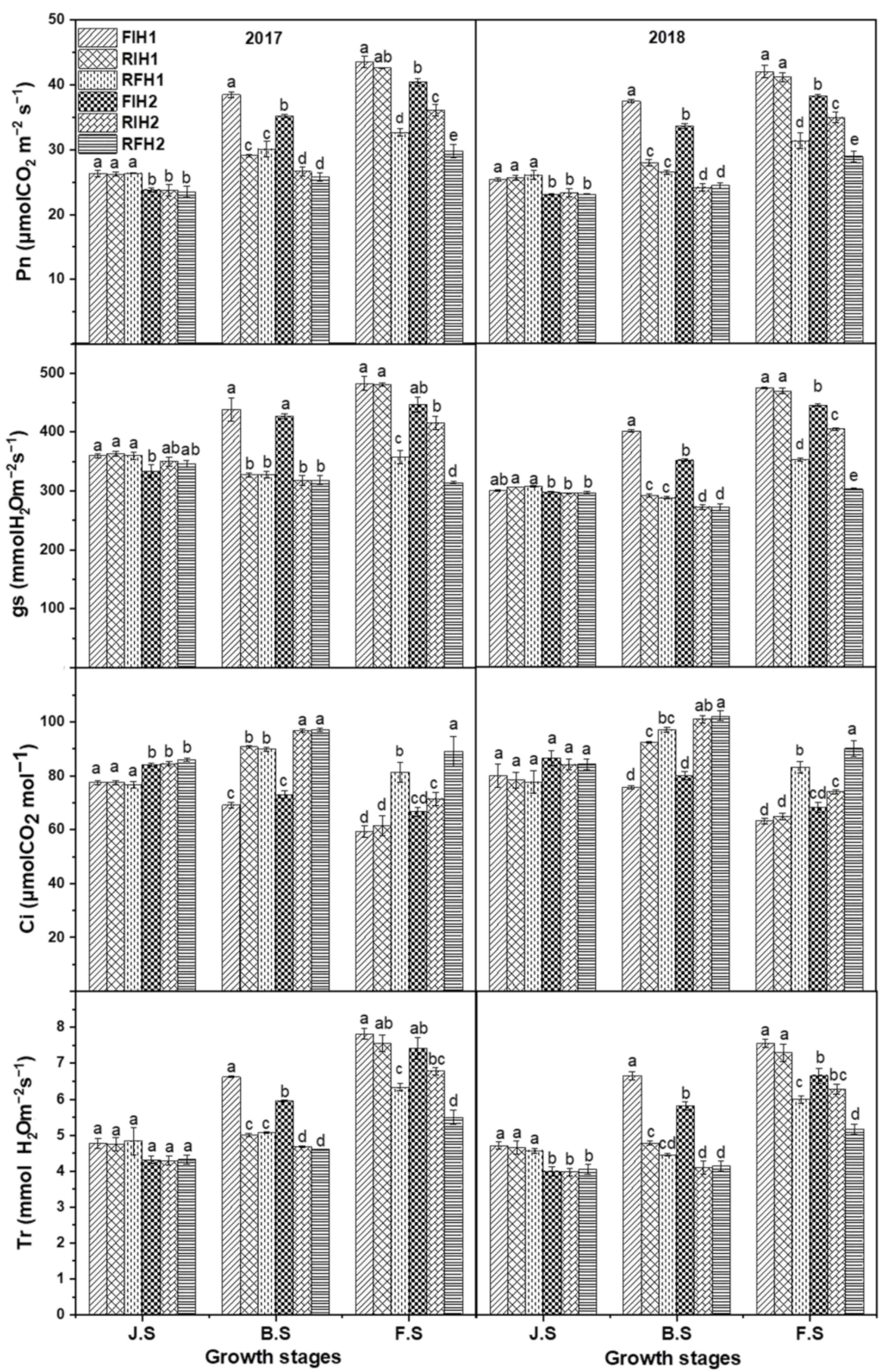

Figure 3. The net photosynthetic rate and leaf gas exchange of maize at different growth stages in the years 2017-2018. In treatments: J.S is the jointing stage, B.S is the big flare stage, and F.S is the flowering stage. FI is full irrigation $(180 \mathrm{~mm}), \mathrm{RI}$ is reproductive irrigation $(60 \mathrm{~mm}), \mathrm{RF}$ is rainfed, H1 is the hybrid Zhengdan 958, and H2 is the hybrid Zhongdan 909. Different letters indicate significant differences among treatments $(p<0.05)$.

\subsection{Dry Matter Accumulation}

The whole plant dry matter accumulation under different water applications and maize hybrids is presented in Table 3 . The results elucidated that $\mathrm{H} 1$ acquired significantly higher biomass accumulation compared with $\mathrm{H} 2$ at the big flare stage. In contrast, at this stage, the dry biomass accumulation in RF was significantly decreased by $16.1 \%(\mathrm{H} 1)$ and $18.0 \%(\mathrm{H} 2)$ in 2017 ; and $18.6 \%(\mathrm{H} 1)$ and $18.4 \%(\mathrm{H} 2)$ 
in 2018, compared with FI. At the flowering stage, the dry biomass accumulation under RF was significantly reduced by $23.9 \%(\mathrm{H} 1)$ and $25.3 \%(\mathrm{H} 2)$ in 2017 ; and $25.0 \%(\mathrm{H} 1)$ and $25.8 \%(\mathrm{H} 2)$ in 2018, compared to FI. However, the dry biomass accumulation was also significantly declined in RF by $19.9 \%(\mathrm{H} 1)$ and $15.0 \%(\mathrm{H} 2)$ in 2017 ; and $21.5 \%(\mathrm{H} 1)$ and $15.7 \%(\mathrm{H} 2)$ in 2018 , compared with RI. The results illuminated that $\mathrm{H} 1$ produced greater dry biomass accumulation compared with $\mathrm{H} 2$ at all growth stages in both years of study (Table 3 ).

\subsection{Yield, Yield Components, and Harvest Index}

The maize cob length, cob diameter, number of lines per cob, number of kernels per cob, and 1000-kernel weight was considerably influenced by the irrigation regimes and hybrids (Table 4). The non-significant differences were noted between the number of kernels per cob and the 1000-kernel weight in FI and RI; however, a significant difference in the hybrids was found in these two yield components (Table 5). In comparative study, we observed that the number of kernels per cob and the 1000-kernel weight significantly decreased in RF by $19.8 \%$ and $8.9 \%(\mathrm{H} 1)$ and $19.0 \%$ and $9.9 \%(\mathrm{H} 2)$ in 2017; and $25.4 \%$ and $8.4 \%(\mathrm{H} 1)$ and $24.7 \%$ and $8.2 \%(\mathrm{H} 2)$ in 2018; respectively, proportionate to FI.

Similarly, RF caused a huge reduction by $18.9 \%$ and $6.8 \%(\mathrm{H} 1)$ and $15.8 \%$ and $6.7 \%(\mathrm{H} 2)$ in 2017; and $23.9 \%$ and $7.9 \%(\mathrm{H} 1)$ and $18.0 \%$ and $6.4 \%(\mathrm{H} 2)$ in 2018; respectively compared with RI (Table 5). On the basis of the yield components, we concluded that the grain yield in RF was significantly reduced by $29.1 \%(\mathrm{H} 1)$ and $29.3 \%(\mathrm{H} 2)$ in 2017 ; and $31.7 \%(\mathrm{H} 1)$ and $32.9 \%(\mathrm{H} 2)$ in 2018 , compared to FI. On the other hand, a huge reduction of grain yield was also noted in RF by $27.4 \%(\mathrm{H} 1)$ and $19.1 \%(\mathrm{H} 2)$ in 2017; and $30.0 \%(\mathrm{H} 1)$ and $21.4 \%(\mathrm{H} 2)$ in 2018, compared to RI. The reduction of grain yield in RF was more in 2018 as compared to 2017 (Table 5). The harvest index between the water irrigation regimes and hybrids are shown in Tables 4 and 5 . The highest harvest index was noted under the treatment of RF with $\mathrm{H} 2$ in both years. 
Table 3. The whole plant dry matter accumulation $\left(\mathrm{kg} \mathrm{ha}^{-1}\right)$ at jointing, big flare, flowering, initial grain, mid grain and physiological maturity stages during the growing season in 2017 and 2018.

\begin{tabular}{|c|c|c|c|c|c|c|c|}
\hline Year & Treatments & Jointing Stage & Big flare Stage & Flowering Stage & Initial grain Stage & Mid grain Stage & Physiological Maturity \\
\hline \multirow[t]{14}{*}{2017} & Irrigations & & & & & & \\
\hline & FI & $1869.98 \pm 94.87 \mathrm{a}$ & $8011.15 \pm 311.11 \mathrm{a}$ & $11255.61 \pm 344.45 \mathrm{a}$ & $18048.36 \pm 841.61 \mathrm{a}$ & $22407.81 \pm 1002.37 \mathrm{a}$ & $23586.64 \pm 880.22 \mathrm{a}$ \\
\hline & RI & $1874.33 \pm 75.47 \mathrm{a}$ & $6766.70 \pm 344.44 \mathrm{~b}$ & $10311.16 \pm 711.11 b$ & $16645.40 \pm 1491.10 \mathrm{~b}$ & $20403.27 \pm 1996.15 b$ & $21519.50 \pm 2414.04 \mathrm{~b}$ \\
\hline & RF & $1880.96 \pm 88.64 \mathrm{a}$ & $6644.47 \pm 333.33 b$ & $8488.93 \pm 333.34 c$ & $12611.67 \pm 900.50 \mathrm{c}$ & $15262.52 \pm 1135.16 \mathrm{c}$ & $15668.84 \pm 885.37 \mathrm{c}$ \\
\hline & Hybrids & & & & & & \\
\hline & $\mathrm{H} 1$ & $1961.42 \pm 43.61 \mathrm{a}$ & $7470.40 \pm 61.72 \mathrm{a}$ & $10481.53 \pm 187.38 \mathrm{a}$ & $16846.22 \pm 239.69 a$ & $20735.76 \pm 412.80 \mathrm{a}$ & $21651.55 \pm 247.90 a$ \\
\hline & $\mathrm{H} 2$ & $1788.76 \pm 31.23 b$ & $6811.14 \pm 108.42 b$ & $9555.60 \pm 155.75 b$ & $14690.74 \pm 245.57 \mathrm{~b}$ & $17979.97 \pm 270.20 \mathrm{~b}$ & $18865.12 \pm 241.80 \mathrm{~b}$ \\
\hline & Interactions & & & & & & \\
\hline & FIH1 & $1964.86 \pm 47.30 \mathrm{a}$ & $8322.26 \pm 67.58 \mathrm{a}$ & $11600.05 \pm 173.20 \mathrm{a}$ & $18889.98 \pm 346.22 \mathrm{a}$ & $23410.17 \pm 372.97 \mathrm{a}$ & $24466.86 \pm 315.07 \mathrm{a}$ \\
\hline & RIH1 & $1949.81 \pm 37.80 \mathrm{a}$ & $7111.14 \pm 58.79 c$ & $11022.27 \pm 292.07 \mathrm{ab}$ & $18136.51 \pm 160.04 \mathrm{a}$ & $22399.42 \pm 462.49 \mathrm{ab}$ & $23933.55 \pm 230.28 a$ \\
\hline & RFH1 & $1969.60 \pm 45.72 \mathrm{a}$ & $6977.81 \pm 58.81 \mathrm{c}$ & $8822.26 \pm 96.86 \mathrm{~d}$ & $13512.17 \pm 212.82 \mathrm{~d}$ & $16397.68 \pm 402.95 \mathrm{~d}$ & $16554.22 \pm 198.26 \mathrm{~d}$ \\
\hline & FIH2 & $1775.11 \pm 39.54 \mathrm{~b}$ & $7700.03 \pm 83.88 \mathrm{~b}$ & $10911.16 \pm 117.58 \mathrm{~b}$ & $17206.75 \pm 97.60 \mathrm{~b}$ & $21405.44 \pm 219.25 b$ & $22706.42 \pm 104.67 \mathrm{~b}$ \\
\hline & RIH2 & $1798.85 \pm 27.97 b$ & $6422.25 \pm 145.72 \mathrm{~d}$ & $9600.04 \pm 195.31 c$ & $15154.29 \pm 270.78 \mathrm{c}$ & $18407.11 \pm 356.23 \mathrm{c}$ & $19105.45 \pm 112.39 c$ \\
\hline & RFH2 & $1792.32 \pm 26.19 b$ & $6311.14 \pm 96.86 \mathrm{~d}$ & $8155.59 \pm 154.36 \mathrm{e}$ & $11711.16 \pm 368.34 \mathrm{e}$ & $14127.36 \pm 235.13 \mathrm{e}$ & $14783.47 \pm 508.34 \mathrm{e}$ \\
\hline \multirow[t]{14}{*}{2018} & Irrigations & & & & & & \\
\hline & FI & $1816.58 \pm 97.63 \mathrm{a}$ & $7909.51 \pm 310.67 a$ & $11041.72 \pm 413.11 \mathrm{a}$ & $17752.27 \pm 725.90 \mathrm{a}$ & $22161.86 \pm 936.29 a$ & $23254.56 \pm 731.55 \mathrm{a}$ \\
\hline & RI & $1828.44 \pm 105.10 \mathrm{a}$ & $6569.86 \pm 314.91 \mathrm{~b}$ & $10146.52 \pm 789.81 \mathrm{~b}$ & $16468.33 \pm 1601.81 \mathrm{~b}$ & $20189.04 \pm 1992.13 b$ & $21045.44 \pm 2366.26 \mathrm{~b}$ \\
\hline & $\mathrm{RF}$ & $1812.79 \pm 97.77 a$ & $6447.13 \pm 247.28 b$ & $8237.41 \pm 348.75 c$ & $12261.47 \pm 869.31 \mathrm{c}$ & $14971.56 \pm 1057.95 \mathrm{c}$ & $15164.66 \pm 1214.09 \mathrm{c}$ \\
\hline & Hybrids & & & & & & \\
\hline & $\mathrm{H} 1$ & $1919.44 \pm 44.40 \mathrm{a}$ & $7266.46 \pm 64.58 \mathrm{a}$ & $10325.78 \pm 170.50 \mathrm{a}$ & $16559.71 \pm 135.50 \mathrm{a}$ & $20436.28 \pm 143.49 a$ & $21258.81 \pm 241.28 \mathrm{a}$ \\
\hline & $\mathrm{H} 2$ & $1719.10 \pm 45.42 b$ & $6684.54 \pm 70.69 \mathrm{~b}$ & $9291.32 \pm 144.61 b$ & $14428.34 \pm 168.34 b$ & $17778.69 \pm 142.90 \mathrm{~b}$ & $18384.25 \pm 257.68 \mathrm{~b}$ \\
\hline & Interactions & & & & & & \\
\hline & FIH1 & $1914.22 \pm 34.27 \mathrm{a}$ & $8220.18 \pm 76.89 a$ & $11454.83 \pm 202.31 \mathrm{a}$ & $18478.17 \pm 121.80 \mathrm{a}$ & $23098.15 \pm 144.63 \mathrm{a}$ & $23986.11 \pm 159.76 \mathrm{a}$ \\
\hline & RIH1 & $1933.54 \pm 39.73 a$ & $6884.78 \pm 16.36 \mathrm{c}$ & $10936.33 \pm 177.02 \mathrm{ab}$ & $18070.14 \pm 153.90 \mathrm{a}$ & $22181.17 \pm 153.35 \mathrm{a}$ & $23411.70 \pm 402.74 \mathrm{ab}$ \\
\hline & RFH1 & $1910.56 \pm 29.93 a$ & $6694.41 \pm 100.52 c$ & $8586.17 \pm 132.17 \mathrm{~d}$ & $13130.78 \pm 130.82 \mathrm{~d}$ & $16029.50 \pm 132.51 \mathrm{~d}$ & $16378.76 \pm 161.35 \mathrm{~d}$ \\
\hline & $\mathrm{FIH} 2$ & $1718.95 \pm 58.79 \mathrm{~b}$ & $7598.84 \pm 61.81 \mathrm{~b}$ & $10628.60 \pm 157.35 \mathrm{~b}$ & $17026.35 \pm 249.78 \mathrm{~b}$ & $21225.57 \pm 172.64 \mathrm{~b}$ & $22523.00 \pm 379.39 \mathrm{~b}$ \\
\hline & RIH2 & $1723.33 \pm 48.67 \mathrm{~b}$ & $6254.94 \pm 64.41 \mathrm{~d}$ & $9356.71 \pm 197.42 c$ & $14866.51 \pm 102.79 \mathrm{c}$ & $18196.90 \pm 134.44 \mathrm{c}$ & $18679.18 \pm 109.99 c$ \\
\hline & RFH2 & $1715.02 \pm 25.75 b$ & $6199.84 \pm 85.82 \mathrm{~d}$ & $7888.66 \pm 79.05 \mathrm{e}$ & $11392.15 \pm 152.45 \mathrm{e}$ & $13913.60 \pm 121.62 \mathrm{e}$ & $13950.56 \pm 283.66 \mathrm{e}$ \\
\hline
\end{tabular}


Table 4. Effects of irrigation regimes and maize hybrids on yield and yield components, harvest index and water use efficiency in growing season 2017 and 2018.

\begin{tabular}{|c|c|c|c|c|c|c|c|c|c|}
\hline Source & SOV & $\begin{array}{c}\text { Cob } \\
\text { Length }\end{array}$ & $\begin{array}{c}\text { Cob } \\
\text { Diameter }\end{array}$ & $\begin{array}{l}\text { No. of Lines } \\
\text { per cob }\end{array}$ & $\begin{array}{l}\text { No. of Kernels } \\
\text { per cob }\end{array}$ & $\begin{array}{l}\text { 1000-Kernel } \\
\text { Weight }\end{array}$ & $\begin{array}{l}\text { Grain } \\
\text { Yield }\end{array}$ & $\begin{array}{l}\text { Harvest } \\
\text { Index }\end{array}$ & $\begin{array}{l}\text { Water Use } \\
\text { Efficiency }\end{array}$ \\
\hline Water $(\mathrm{W})$ & 2 & $199.11^{* *}$ & $181.83^{* *}$ & $95.84^{* *}$ & $163.25^{* *}$ & $40.18^{*}$ & $1940.63^{* *}$ & 13.50 * & $847.08^{* *}$ \\
\hline Hybrid (H) & 1 & $53.75^{* *}$ & $19.22 * *$ & $437.85^{* *}$ & $148.07^{* *}$ & 15.79 * & $267.76^{* *}$ & $50.50^{* *}$ & $244.06^{* *}$ \\
\hline $\mathrm{W} \times \mathrm{H}$ & 2 & 0.53 & 0.23 & $23.01 * *$ & 7.35 * & 0.22 & $50.49 * *$ & 11.18 * & $49.36^{* *}$ \\
\hline Year $(\mathrm{Y})$ & 1 & $190.63 * *$ & $643.06^{* *}$ & $15.85^{* *}$ & $7.86^{*}$ & $18.04^{* *}$ & $57.15 * *$ & 0.85 * & $6.01 *$ \\
\hline $\mathrm{Y} \times \mathrm{W}$ & 2 & 0.27 & 0.30 & 0.84 & 2.42 & 0.46 & 2.06 & 1.11 & 2.56 \\
\hline $\mathrm{Y} \times \mathrm{H}$ & 1 & 0.34 & 0.32 & 0.52 & 0.59 & 2.06 & 0.02 & 0.62 & 0.48 \\
\hline $\mathrm{Y} \times \mathrm{W} \times \mathrm{H}$ & 2 & 0.14 & 0.21 & 0.69 & 0.30 & 0.09 & 0.18 & 0.46 & 0.36 \\
\hline
\end{tabular}

In the columns; SOV indicates the source of variation. ${ }^{* *}$ and ${ }^{*}$ indicate significance at $p<0.01$ and $<0.05$, respectively. 
Table 5. Effects of different irrigation and maize hybrids on grain yield and yield components in season 2017 and 2018.

\begin{tabular}{|c|c|c|c|c|c|c|}
\hline Year & Treatments & No. of Kernel cob $^{-1}$ & 1000-Kernel Weight (g) & Grain Yield (kg ha-1) & WUE (kg ha $\left.{ }^{-1} \mathrm{~mm}^{-1}\right)$ & Harvest Index (\%) \\
\hline \multirow[t]{14}{*}{2017} & Irrigations & & & & & \\
\hline & FI & $522.97 \pm 25.91 \mathrm{a}$ & $333.86 \pm 2.76 \mathrm{a}$ & $11950.68 \pm 337.67 \mathrm{a}$ & $15.92 \pm 0.45 b$ & $54.08 \pm 0.33 b$ \\
\hline & RI & $510.51 \pm 31.91 \mathrm{a}$ & $324.72 \pm 4.97 \mathrm{a}$ & $11085.28 \pm 928.13 b$ & $17.58 \pm 1.47 \mathrm{a}$ & $55.12 \pm 1.62 \mathrm{ab}$ \\
\hline & RF & $421.40 \pm 18.15 b$ & $302.36 \pm 4.18 b$ & $8465.61 \pm 251.32 c$ & $14.72 \pm 0.43 c$ & $57.42 \pm 1.21 \mathrm{a}$ \\
\hline & Hybrids & & & & & \\
\hline & $\mathrm{H} 1$ & $510.28 \pm 11.53 \mathrm{a}$ & $324.29 \pm 4.21 \mathrm{a}$ & $11006.23 \pm 116.11 \mathrm{a}$ & $16.86 \pm 0.18 \mathrm{a}$ & $54.48 \pm 0.46 \mathrm{a}$ \\
\hline & $\mathrm{H} 2$ & $459.64 \pm 8.62 b$ & $316.34 \pm 6.11 b$ & $9994.81 \pm 108.11 \mathrm{~b}$ & $15.29 \pm 0.17 b$ & $56.61 \pm 1.22 \mathrm{a}$ \\
\hline & Interactions & & & & & \\
\hline & FIH1 & $548.87 \pm 10.94 \mathrm{a}$ & $336.62 \pm 2.98 \mathrm{a}$ & $12288.28 \pm 96.45 a$ & $16.38 \pm 0.13 b$ & $53.74 \pm 0.27 b$ \\
\hline & RIH1 & $542.42 \pm 9.28 \mathrm{a}$ & $329.07 \pm 5.01 \mathrm{a}$ & $12013.42 \pm 98.44 \mathrm{a}$ & $19.06 \pm 0.16 a$ & $53.49 \pm 0.68 b$ \\
\hline & RFH1 & $439.66 \pm 14.29 \mathrm{c}$ & $306.55 \pm 4.64 b$ & $8716.93 \pm 153.44 \mathrm{~d}$ & $15.15 \pm 0.27 c$ & $56.21 \pm 0.42 \mathrm{ab}$ \\
\hline & FIH2 & $497.07 \pm 8.61 \mathrm{~b}$ & $331.10 \pm 6.70 \mathrm{a}$ & $11613.02 \pm 57.97 b$ & $15.48 \pm 0.08 c$ & $54.42 \pm 0.40 \mathrm{~b}$ \\
\hline & $\mathrm{RIH} 2$ & $478.33 \pm 12.74 b c$ & $319.74 \pm 2.09 \mathrm{ab}$ & $10157.14 \pm 161.29 \mathrm{c}$ & $16.12 \pm 0.26 b$ & $56.75 \pm 0.74 \mathrm{ab}$ \\
\hline & $\mathrm{RFH} 2$ & $402.66 \pm 4.63 \mathrm{~d}$ & $298.17 \pm 9.41 b$ & $8214.23 \pm 104.99 \mathrm{e}$ & $14.29 \pm 0.18 \mathrm{~d}$ & $58.63 \pm 2.53 \mathrm{a}$ \\
\hline \multirow[t]{14}{*}{2018} & Irrigations & & & & & \\
\hline & FI & $521.88 \pm 18.11 \mathrm{a}$ & $319.67 \pm 7.15 \mathrm{a}$ & $11651.35 \pm 300.33 \mathrm{a}$ & $16.31 \pm 0.42 b$ & $53.22 \pm 0.11 b$ \\
\hline & RI & $496.14 \pm 33.47 \mathrm{~b}$ & $315.86 \pm 9.34 b$ & $10672.74 \pm 974.26 b$ & $17.96 \pm 1.63 a$ & $54.12 \pm 1.21 \mathrm{ab}$ \\
\hline & $\mathrm{RF}$ & $391.21 \pm 11.79 c$ & $293.16 \pm 6.31 c$ & $7884.61 \pm 266.98 c$ & $14.65 \pm 0.49 c$ & $55.32 \pm 2.24 \mathrm{a}$ \\
\hline & Hybrids & & & & & \\
\hline & $\mathrm{H} 1$ & $490.85 \pm 6.91 \mathrm{a}$ & $317.17 \pm 3.67 \mathrm{a}$ & $10583.43 \pm 130.15 a$ & $17.16 \pm 0.21 \mathrm{a}$ & $53.13 \pm 0.91 b$ \\
\hline & $\mathrm{H} 2$ & $448.62 \pm 7.26 b$ & $301.96 \pm 2.99 b$ & $9555.71 \pm 112.11 b$ & $14.45 \pm 0.17 b$ & $55.37 \pm 0.91 \mathrm{a}$ \\
\hline & Interactions & & & & & \\
\hline & FIH1 & $539.95 \pm 3.45 \mathrm{a}$ & $326.84 \pm 4.03 \mathrm{a}$ & $11951.69 \pm 194.09 \mathrm{a}$ & $16.74 \pm 0.27 b$ & $53.32 \pm 0.66 b$ \\
\hline & RIH1 & $529.62 \pm 7.71 \mathrm{a}$ & $325.21 \pm 3.27 \mathrm{a}$ & $11647.34 \pm 70.51 \mathrm{ab}$ & $19.60 \pm 0.12 a$ & $52.99 \pm 1.34 b$ \\
\hline & RFH1 & $403.00 \pm 9.29 \mathrm{~d}$ & $299.48 \pm 3.40 \mathrm{~cd}$ & $8151.60 \pm 125.86 \mathrm{~d}$ & $15.14 \pm 0.23 \mathrm{~d}$ & $53.07 \pm 0.70 b$ \\
\hline & FIH2 & $503.81 \pm 6.58 \mathrm{~b}$ & $312.50 \pm 1.50 \mathrm{ab}$ & $11351.02 \pm 161.20 \mathrm{~b}$ & $15.90 \pm 0.23 c$ & $53.12 \pm 0.93 b$ \\
\hline & $\mathrm{RIH} 2$ & $462.67 \pm 10.33 c$ & $306.52 \pm 4.35 \mathrm{bc}$ & $9698.48 \pm 72.21 \mathrm{c}$ & $16.32 \pm 0.12 b c$ & $55.43 \pm 0.29 \mathrm{ab}$ \\
\hline & RFH2 & $379.40 \pm 4.89 \mathrm{e}$ & $286.85 \pm 4.14 \mathrm{~d}$ & $7617.62 \pm 102.71 \mathrm{e}$ & $14.16 \pm 0.19 \mathrm{e}$ & $57.57 \pm 1.56 \mathrm{a}$ \\
\hline
\end{tabular}

Note: Different letters indicate significant differences among treatments $(p<0.05)$. 


\subsection{Water Use Efficiency}

The water use efficiency (WUE) was found to be lower in RF compared to FI and RI (Tables 4 and 5). However, the H1 hybrids had greater water use efficiency compared to H2 in 2017-2018. In this study, the WUE under rainfed was significantly reduced by $7.50 \%(\mathrm{H} 1)$ and $7.68 \%(\mathrm{H} 2)$ in 2017 ; and $9.55 \%(\mathrm{H} 1)$ and $10.94 \%(\mathrm{H} 2)$ in 2018 compared with FI. Similarly, it was also decreased significantly by $20.51 \%(\mathrm{H} 1)$ and $11.35 \%$ (H2) in 2017; and 22.75\% (H1) and 13.23\% (H2) in 2018 compared with RI (Tables 4 and 5).

\section{Discussion}

Rainfed treated maize plants have an enormous compromise of grain yield as compared to those in fully irrigated conditions. However, there was less difference found in the grain yield at reproductive irrigation compared to the grain yield at fully irrigated frequencies. We found a substantial difference in the grain yield under rainfed conditions due to the increased anthesis-silking interval (ASI) due to flowering drought stress.

Flowering time is a key event as plants shift from vegetative to reproductive growth, moving toward harvestable yield. In our study, under rainfed conditions, the number of kernels decreased by $17.7 \%$ in 2017 and $21.1 \%$ in 2018 , compared with RI. Other studies observed a significant decrease in number of kernels by 31.13\% [27], and 19\% [28] under drought stress during flowering period. Maize crops were found to be particularly susceptible to drought at the flowering stage [29]. In addition, the grain yield decreased by $23.6 \%$ in 2017 and $26.1 \%$ in 2018 under rainfed conditions, compared with RI. Other studies also observed significant reduction in grain yield by 53\% [17], 50\% [30], and 34.28 to $66.15 \%$ susceptible to drought and 38.48 to $55.95 \%$ in drought-tolerant hybrids particularly severe when drought stress occurs at the flowering stage [31].

Source activity and sink capacity can be affected by water deficits by reducing the leaf area accelerating leaf senescence [32]. Our results showed that, under rainfed conditions, dry biomass accumulation, and Pn decreased by $17.7 \%$, and $20.7 \%$ in 2017 and $18.8 \%$, and $20.9 \%$ in 2018, respectively, compared with RI. Our results were supported by another study, where dry matter loss during tasseling stage were recorded as $25 \%$ and $19.2 \%$ under water deficit condition [13]. Another research study reported that a $55.1 \%$ reduction in photosynthetic rate was observed at flowering stage [33]. Another researcher demonstrated reduced net photosynthesis to a comparable extent at both pre- and post-pollination stages under water deficit condition, to less than $10 \%$ of controls [34]. We found similar results in our study where irrigation at the flowering stage and rainfed decreased the Pn rate as compared to full irrigation.

We observed that the application of reproductive irrigation at the flowering stage was more important as it led to the synchronous process of anthesis and silking, which, in turn, favored good pollination and resulted in more kernel setting, ultimately increasing the grain yield with lower amounts of water. In addition, we applied $60 \mathrm{~mm}$ irrigation at the flowering stage using the flooded method to obtain the maximum grain yield; however, a large water loss occurred through seepage.

While the future is difficult to predict, available freshwater resources will certainly decrease in the coming years due to the increasing demands of a growing world population. Many areas of the world are already experiencing a shortage of water resources. In this study, $60 \mathrm{~mm}$ irrigation was applied during the flowering stage. Whether this is optimal remains to be determined. Crop models can assist to optimize the irrigation amount. For example, the APSIM-Maize model [35] was used to predict drought impacts on maize production [36]. Thus, APSIM-Maize may be helpful in assessing the optimal irrigation during flowering.

In this study, we observed the performance of maize hybrids in the grain yield and water use efficiency. Across the irrigation, Zhongdan 909 (H2) expressed lower grain yield and WUE as compared to Zhengdan 958 (H1). In our observations, H1 was more drought-tolerant at the flowering stage compared to H2. Our results are line with a study showing that drought resistant maize hybrids performed very well under water-limited conditions [37]. Drought tolerance was characterized by having a shorter anthesis-silking interval (ASI) [38], and a higher number of kernels/ear [39,40]. 
The proper selection of drought hybrids can increase the grain yield with a greater biomass and harvest index $(\mathrm{HI})$, greater kernel weight, and higher water use efficiency under water-limited conditions [41-43].

Maintaining favorable plant-soil-water relations throughout the entire growing season is important to stabilize plant growth and development for high yield under water-limited conditions [44,45]. However, few previous studies focused on the difference in soil water extraction patterns and evapotranspiration (ET) between conventional and drought-tolerant hybrids at different growing stages under water-limited conditions [46-49].

\section{Conclusions}

In this study, we compared the responses of leaf gas exchange, growth, grain yield, and water use efficiency of maize hybrids to different irrigation regimes. Results of this study showed that irrigation regimes significantly influenced maize hybrids, growth and development by altering leaf gas exchange and source to sink relationship. Results of this study revealed that the grain yield in rainfed conditions demonstrated a huge compromise compared with the potential yield achieved under fully irrigated conditions due to the loss of kernels caused by water stress during flowering. Irrigation during flowering $(60 \mathrm{~mm})$ had a considerable increase in the grain yield and almost reached $93.0 \%$ of the fully irrigated $(180 \mathrm{~mm})$ results. The WUE also showed an increase. Thus, the application of irrigation during flowering should be recommended, combined with the use of Zhengdan 958 for greater maize grain yield and efficiency of resource utilization in Huaibei plain or in similar conditions.

Author Contributions: M.I.A. and A.N.S.; contributed equally to this work. J.S.; helped in formatting. Y.S.; helped to improve the draft by providing useful suggestions. All authors have read and agreed to the published version of the manuscript.

Funding: The work was supported by a grant from China National Key Research and Development Program (2017YFD0301307), and the Anhui Agricultural University startup fund for YS.

Conflicts of Interest: The authors declare no conflict of interest.

\section{References}

1. Lobell, D.B.; Baldos, U.L.C.; Hertel, T.W. Climate adaptation as mitigation: The case of agricultural investments. Environ. Res. Lett. 2013, 8, 015012. [CrossRef]

2. Pourdad, S.; Beg, A. Safflower: A suitable oilseed crop for dry-land areas of Iran. In Proceedings of the 7th International Conference on Development of Dry Lands, Tehran, Iran, 14-17 September 2003.

3. Li, D.; Qi, H.; Ma, X. The climate index and assessment about drought and flood in maize's key growth stage in Huaibei Plain in Anhui Province. Chin. Agric. Sci. Bull. 2013, 29, 208-216.

4. Wu, F.; Guclu, H. Global maize trade and food security: Implications from a social network model. Risk Anai. 2013, 33, 2168-2178. [CrossRef] [PubMed]

5. Liu, Y.; Li, S.; Chen, F.; Yang, S.; Chen, X. Soil water dynamics and water use efficiency in spring maize (Zea mays L.) fields subjected to different water management practices on the Loess Plateau, China. Agric. Water Manag. 2010, 97, 769-775. [CrossRef]

6. CIMMYT, I. Maize-Global Alliance for Improving Food Security and the Livelihoods of the Resource-poor in the Developing World; CIMMYT: Mexico City, Mexico, 2010.

7. Rurinda, J.; Van Wijk, M.T.; Mapfumo, P.; Descheemaeker, K.; Supit, I.; Giller, K.E. Climate change and maize yield in southern Africa: What can farm management do? Glob. Chang. Biol. 2015, 21, 4588-4601. [CrossRef]

8. Žalud, Z.; Hlavinka, P.; Prokeš, K.; Semerádová, D.; Jan, B.; Trnka, M. Impacts of water availability and drought on maize yield-A comparison of 16 indicators. Agric. Water Manag. 2017, 188, 126-135. [CrossRef]

9. Pandey, R.; Maranville, J.; Admou, A. Deficit irrigation and nitrogen effects on maize in a Sahelian environment: I. Grain yield and yield components. Agric. Water Manag. 2000, 46, 1-13. [CrossRef]

10. Wei, Y.; Jin, J.; Jiang, S.; Ning, S.; Cui, Y.; Zhou, Y. Simulated assessment of summer maize drought loss sensitivity in Huaibei Plain, China. Agronomy 2019, 9, 78. [CrossRef] 
11. Farooq, M.; Wahid, A.; Kobayashi, N.; Fujita, D.; Basra, S. Plant drought stress: Effects, mechanisms and management. In Sustain AGR; Springer: Berlin/Heidelberg, Germany, 2009; pp. 153-188.

12. Ge, T.; Sui, F.; Bai, L.; Tong, C.; Sun, N. Effects of water stress on growth, biomass partitioning, and water-use efficiency in summer maize (Zea mays L.) throughout the growth cycle. Acta Physiol. Plant. 2012, 34, 1043-1053. [CrossRef]

13. Çakir, R. Effect of water stress at different development stages on vegetative and reproductive growth of corn. Field Crop. Res. 2004, 89, 1-16. [CrossRef]

14. Farre, I.; Faci, J.M. Comparative response of maize (Zea mays L.) and sorghum (Sorghum bicolor L. Moench) to deficit irrigation in a Mediterranean environment. Agric. Water Manag. 2006, 83, 135-143. [CrossRef]

15. Panda, R.; Behera, S.; Kashyap, P. Effective management of irrigation water for maize under stressed conditions. Agric. Water Manag. 2004, 66, 181-203. [CrossRef]

16. Otegui, M.E.; Andrade, F.H. New relationships between light interception, ear growth, and kernel set in maize. Physiol. Model. Kernel Set Maize 2000, 29, 89-102.

17. Claasen, M.; Shaw, R. Water deficit effects on corn. II. Grain components. Agron. J. 1970, 62, $652-655$. [CrossRef]

18. NeSmith, D.; Ritchie, J. Short-and long-term responses of corn to a pre-anthesis soil water deficit. Agron. J. 1992, 84, 107-113. [CrossRef]

19. Aguilar, M.; Muñoz, F.B.; Espinosa, M. Agronomic response of maize to limited levels of water under furrow irrigation in southern Spain. Span. J. Agric. Res. 2007, 5, 587-592. [CrossRef]

20. Li, W.; Qiao, Y.; Chen, H.; Cao, C.; Du, S.; Zhao, Z. Effects of combined straw and N application on the physicochemical properties of lime concretion black soil and crop yields. Acta. Ecol. Sin. 2014, 34, 5052-5061.

21. Wang, T.-C.; Wei, L.; Wang, H.-Z.; Ma, S.-C.; Ma, B. Responses of rainwater conservation, precipitation-use efficiency and grain yield of summer maize to a furrow-planting and straw-mulching system in northern China. Field Crop. Res. 2011, 124, 223-230. [CrossRef]

22. Wang, D.; Mu, Y.; Hu, X.; Ma, B.; Wang, Z.; Zhu, L.; Xu, J.; Huang, C.; Pan, Y.; Comparative proteomic analysis reveals that the heterosis of two maize hybrids related to enhancement of stress response and photosynthesis respectively. Research Square. 2020. Available online: https://www.researchsquare.com/article/rs-29700/v1 (accessed on 11 August 2020).

23. Shah, A.N.; Yang, G.; Tanveer, M.; Iqbal, J. Leaf gas exchange, source-sink relationship, and growth response of cotton to the interactive effects of nitrogen rate and planting density. Acta. Physiol. Plant. 2017, 39, 119. [CrossRef]

24. Dray, F.A.; Center, T.D.; Mattison, E.D. In situ estimates of waterhyacinth leaf tissue nitrogen using a SPAD-502 chlorophyll meter. Aquat. Bot. 2012, 100, 72-75. [CrossRef]

25. Daynard, T.; Duncan, W.G. The Black Layer and Grain Maturity in Corn 1. Crop. Sci. 1969, 9, 473-476. [CrossRef]

26. Amanullah; Inamullah. Dry Matter Partitioning and Harvest Index Differ in Rice Genotypes with Variable Rates of Phosphorus and Zinc Nutrition. Rice Sci. 2016, 23, 78-87. [CrossRef]

27. Al-Naggar, A.; Soliman, S.; Hashimi, M. Tolerance to drought at flowering stage of 28 maize hybrids and populations. Egypt. J. Plant Breed 2011, 15, 69-87.

28. Li, Y.; Tao, H.; Zhang, B.; Huang, S.; Wang, P. Timing of water deficit limits maize kernel setting in association with changes in the source-flow-sink relationship. Front. Plant Sci. 2018, 9, 1326. [CrossRef]

29. Chapman, S.C.; Crossa, J.; Edmeades, G.O. Genotype by environment effects and selection for drought tolerance in tropical maize. I. Two mode pattern analysis of yield. Euphytica 1997, 95, 01-09. [CrossRef]

30. Denmead, O.; Shaw, R.H. The Effects of Soil Moisture Stress at Different Stages of Growth on the Development and Yield of Corn 1. Agron. J. 1960, 52, 272-274. [CrossRef]

31. Sah, R.; Chakraborty, M.; Prasad, K.; Pandit, M.; Tudu, V.; Chakravarty, M.; Narayan, S.; Rana, M.; Moharana, D. Impact of water deficit stress in maize: Phenology and yield components. Sci. Rep. 2020, 10, 2944. [CrossRef]

32. Prochazkova, D.; Sairam, R.; Srivastava, G.; Singh, D. Oxidative stress and antioxidant activity as the basis of senescence in maize leaves. Plant Sci. 2001, 161, 765-771. [CrossRef]

33. Atteya, A. Alteration of water relations and yield of corn genotypes in response to drought stress. Bulg. J. Plant Physiol. 2003, 29, 63-76. 
34. Setter, T.L.; Flannigan, B.A.; Melkonian, J. Loss of kernel set due to water deficit and shade in maize. Crop. Sci. 2001, 41, 1530-1540. [CrossRef]

35. Keating, B.A.; Carberry, P.S.; Hammer, G.L.; Probert, M.E.; Robertson, M.J.; Holzworth, D.; Huth, N.I.; Hargreaves, J.N.; Meinke, H.; Hochman, Z. An overview of APSIM, a model designed for farming systems simulation. Eur. J. Agron. 2003, 18, 267-288. [CrossRef]

36. Song, Y.; Birch, C.; Qu, S.; Doherty, A.; Hanan, J. Analysis and modelling of the effects of water stress on maize growth and yield in dryland conditions. Plant Prod. Sci. 2010, 13, 199-208. [CrossRef]

37. Mounce, R.B.; O'Shaughnessy, S.A.; Blaser, B.C.; Colaizzi, P.D.; Evett, S.R. Crop response of drought-tolerant and conventional maize hybrids in a semiarid environment. Irrig. Sci. 2016, 34, 231-244. [CrossRef]

38. Bolaños, J.; Edmeades, G. The importance of the anthesis-silking interval in breeding for drought tolerance in tropical maize. Field Crop. Res. 1996, 48, 65-80. [CrossRef]

39. Hall, A.; Vilella, F.; Trapani, N.; Chimenti, C. The effects of water stress and genotype on the dynamics of pollen-shedding and silking in maize. Field Crop. Res. 1982, 5, 349-363. [CrossRef]

40. Ribaut, J.-M.; Jiang, C.; Gonzalez-de-Leon, D.; Edmeades, G.; Hoisington, D. Identification of quantitative trait loci under drought conditions in tropical maize. 2. Yield components and marker-assisted selection strategies. Theor. Appl. Genet. 1997, 94, 887-896. [CrossRef]

41. Hao, B.; Xue, Q.; Marek, T.; Jessup, K.; Hou, X.; Xu, W.; Bynum, E.; Bean, B. Radiation-use efficiency, biomass production, and grain yield in two maize hybrids differing in drought tolerance. J. Agron. Crop. Sci. 2016, 202, 269-280. [CrossRef]

42. Boomsma, C.R.; Vyn, T.J. Maize drought tolerance: Potential improvements through arbuscular mycorrhizal symbiosis? Field Crop. Res. 2008, 108, 14-31. [CrossRef]

43. Hao, B.; Xue, Q.; Marek, T.; Jessup, K.; Becker, J.; Hou, X.; Xu, W.; Bynum, E.; Bean, B.; Colaizzi, P. Water use and grain yield in drought-tolerant corn in the Texas High Plains. Agron. J. 2015, 107, 1922-1930. [CrossRef]

44. Campos, H.; Cooper, M.; Habben, J.; Edmeades, G.; Schussler, J. Improving drought tolerance in maize: A view from industry. Field Crop. Res. 2004, 90, 19-34. [CrossRef]

45. Cooper, M.; Gho, C.; Leafgren, R.; Tang, T.; Messina, C. Breeding drought-tolerant maize hybrids for the US corn-belt: Discovery to product. J. Exp. Bot. 2014, 65, 6191-6204. [CrossRef] [PubMed]

46. Aydinsakir, K.; Erdal, S.; Buyuktas, D.; Bastug, R.; Toker, R. The influence of regular deficit irrigation applications on water use, yield, and quality components of two corn (Zea mays L.) genotypes. Agric. Water Manag. 2013, 128, 65-71. [CrossRef]

47. Ali, Q.; Ahsan, M.; Kanwal, N.; Ali, F.; Ali, A.; Ahmed, W.; Ishfaq, M.; Saleem, M. Screening for drought tolerance: Comparison of maize hybrids under water deficit condition. Adv. Life Sci. 2016, 3, 51-58.

48. Avramova, V.; Nagel, K.A.; AbdElgawad, H.; Bustos, D.; DuPlessis, M.; Fiorani, F.; Beemster, G.T. Screening for drought tolerance of maize hybrids by multi-scale analysis of root and shoot traits at the seedling stage. J. Exp. Bot. 2016, 67, 2453-2466. [CrossRef]

49. Cano, E.; Musarella, C.M.; Cano-Ortiz, A.; Piñar Fuentes, J.C.; Rodríguez Torres, A.; Del Río González, S.; Pinto Gomes, C.J.; Quinto-Canas, R.; Spampinato, G. Geobotanical Study of the Microforests of Juniperus oxycedrus subsp. badia in the Central and Southern Iberian Peninsula. Sustainability 2019, 11, 1111. [CrossRef]

(C) 2020 by the authors. Licensee MDPI, Basel, Switzerland. This article is an open access article distributed under the terms and conditions of the Creative Commons Attribution (CC BY) license (http://creativecommons.org/licenses/by/4.0/). 